\title{
From Hospitality to Hostility: Border Crossing Experiences among Unsung Heroes on the Wheel in COVID-19-Hit East Africa
}

\author{
Switbert R. Kamazima ${ }^{1^{*}}$, Method Kazaura ${ }^{2}$ and \\ Deodatus C. V. Kakoko ${ }^{1}$
}

\author{
${ }^{1}$ Behavioral Sciences Department, School of Public Health and Social Sciences, Muhimbili \\ University of Health and Allied Sciences, P. O. Box 65001, Dar-es-Salaam, Tanzania
}

${ }^{2}$ Epidemiology and Biostatistics Department, School of Public Health and Social Sciences, Muhimbili University of Health and Allied Sciences, P. O. Box 65001, Dar-es-Salaam, Tanzania

\begin{abstract}
Coronavirus 2019 disease (COVID-19) has spread all over the world affecting 213 countries. Efforts to control the spread of the pandemic are enormous. In this paper, we use a case of the unsung heroes on the wheel delivering essential goods and services in the COVID19-hit region to demonstrate how closing border for the public health good and mandatory COVID-19 screening among the truckers have impacted the flow of goods and services and are eroding amicable relationships that existed among truckers, communities and East African states. We collected and reviewed different documents including published papers, grey literature, newspapers, media information, formal and informal reports and conducted formal and informal discussions with interested parties. Closing borders undertaken by the East African states, except Tanzania, halted cross borer activities. Where border crossing is allowed, truck drivers from partner states are required to practice relay driving/trucking or offloading their cargo at the border crossing points. Mandatory COVID-19 testing among the truck drivers has resulted into truckers' crowding and resentment among neighboring states. We conclude that lack of collective will to fight COVID-19 led to uncoordinated measures in the region thus disrupting the free movement of people, goods and services and are eroding amicable relationships that previously existed in East Africa.
\end{abstract}

Key words: Truck drivers, Coronavirus, COVID-19, East Africa, East African Community Partner States.

\section{Introduction}

Like the rest of the world, East African countries are facing Coronavirus 2019 disease (COVID-19), an infectious sickness caused by severe acute respiratory syndrome coronavirus 2 (SARS-CoV-2) [1]. Since the recognition of the disease in Wuhan, China, in December 2019 ([2], COVID-19 has spread all over the world affecting 213 countries, infecting 26,184,508 people, with $18,448,187$ recoveries and 867,374 deaths as per September 3, 2020 at 6:41 GMT [3]. To control the spread of the pandemic, nations have been forced to intervene and issue directions under executive orders to ensure the pandemic is contained [4]. East African countries, for example, have put in place several precautionary measures to mitigate the pandemic including: frequent hand washing with soap and running water; closing schools, colleges and universities; social distancing; staying at home; wearing face masks when in public places; avoiding crowded places and unnecessary movements; curfews; lockdown and closing borders for the public health good.

Kenya reported the first COVID-19 case in East Africa on March 12, 2020 followed by Rwanda (March 14, 2020), Tanzania (March 16, 2020), Uganda (March 20, 2020), Burundi (March 31, 2020) and South Sudan (April 5, 2020). Indeed, the pandemic is affecting all sectors of social, economic and political life. In this paper, however, we use a case of the unsung heroes on the wheel (the long-distance cross border truck drivers) delivering essential goods and services in the COVID19-hit region to demonstrate how government-imposed 
International Journal of Advanced Scientific Research and Management, Volume 5 Issue 9, Sep 2020

measures to control the spread of the lethal coronavirus: closing the borders for the public health good and mandatory COVID-19 testing among truck drivers, in particular, are 1) disrupting the free movement of people, goods and services in the region during the COVID-19 pandemic, and 2) eroding amicable relationships that previously existed among the truck drivers; between communities along the transit routes/interregional highways and the truck drivers; between the truck drivers and the border authorities and somehow between adjoining East African Community (EAC) Partner States. To achieve this objective, we collected and reviewed different documents including published papers, grey literature, newspapers, media information, formal and informal reports and conducted formal and informal discussions with interested parties.

\section{East African Community guidelines during CIVID-19 pandemic}

On March 25, 2020, the Ministers responsible for Health and East African Community Affairs issued a joint statement on COVID-19 Preparedness and Response in East African Community Region. The Ministers recognized, among other issues, 1) the vital role played by the long-distance truck drivers in the region during the COVID-19 pandemic; 2) that different Partner States were taking different measures to combat the pandemic; 3) that WHO has and is continuously providing guidelines on what measures to be taken during the period of the pandemic; 4) guidelines by the World Customs Organization facilitating the movement of goods to contain COVID-19; 5) that COVID-19 had disrupted the usual movement of goods and services in the region; 6) that in order to sustain lives of the people of East Africa, the movement of goods and services have to continue; and 7) the need to facilitate the free movement of goods and services in the region during the COVID-19 pandemic period [5].

In the same perspective, the EAC introduced the Administrative Guidelines for application during the COVID-19 pandemic period with the following objectives: 1) to complement national measures against the COVID-19 pandemic; 2) to ensure smooth and uninterrupted movement of goods and services during the COVID-19 pandemic; 3) to encourage local production of essential products during this COVID-19 pandemic; 4) to enhance regional awareness on measures instituted against COVID-19 pandemic; and 5) to mitigate the negative impact of COVID-19 pandemic on the movements of goods and services in the region [6].

The guidelines require Partner States to contiue facilitating the movement of goods and services from and to the the Partner States during the the COVID-19 pandemic. Recommended measures include: 1) providing access to all desgniated points for entry and exit of goods; 2) treating cross-border movement of truck and cargo as essential services; 3) directing transporters and Transporters' Associations to adhere to requirement of having only two (2) to three (3) operators of the truck including the driver; 4) enforcing mandatory screening or testing of truck drivers and crew at border points and undertake monitoring during transit at selected points; 5) quarantining those with symptoms for 14 days under the supervision of the Ministry of Health; and 7) treating drivers and crew who have tested for COVID-19 and found positive in the host Partner State where the test was carried out. Importantly, Partner States are argued not to repatriate infected drivers and the crew to country of origin to avoid the spread of COVID-19 [6].

Furthermore, Partner States are urged to: 1) promote local production of items required to contains COVID19 pandemic, for example, medicaments, sanitizers, protective gear and ventilators; 2) put in place arrangements to screen or test all cross-border truck drivers at least twice per month or just before they commence their trip to neighboring Partner State; 3) allow truck drivers and crew to proceed with their trip upon being tested at border points awaiting communication on results of the tests and 4) designate specific points along the transit routes throughout the region where truck drivers and crew can recuperate without mingling with the local communities, such resting places be communicated to other Partner States and the EAC Secretariat and 5) harmonise restricitions to ensure common interpretion and application [6].

In this line, EAC Partner States have instituted containmnent measures including: 1) restricitng citizens' movement, curfews and partial/full lockdown; 2) restricitng free movement of cargo across the region by air, road and sea; 3 ) restricting to a maximum of three accompanying persons per truck, 4) adhering to strict respitatory hygiene and sanitation guidelines (washing and sanitizing hands regularly), and 5) closing borders for the public health good [6]. 
International Journal of Advanced Scientific Research and Management, Volume 5 Issue 9, Sep 2020

\section{Border closing and mandatory COVID-19 testing among truck drivers}

\subsection{Tanzania-Rwanda border}

Rwanda was the first country in the region to close its borders with neighboring countries Tanzania and Burundi on March 21, 2020. The Rwanda-Uganda border had been closed following misunderstandings between the two Partner States. By mid-May, 2020, "Rwanda had imposed requirements of a relay system that would allow handling over of cargo trucks to Rwandese drivers at border points, offloading cargo at border points as well as COVID-19 clearance certificate for truck drivers" [7-9]). Truck drivers from other Partner States, therefore, were required to stop at the border, sanitize their vehicles and pass along their goods to a Rwandese driver so they do not cross international border into Rwanda or offload cargo to Rwandese trucks at border points (relay driving/trucking). In case of the in-transit cargo, the Rwandese driver similarly hands over the truck to another driver at the border crossing after the vehicle is sanitized $[19,11]$.

The two conditions were too bitter to swallow by the truckdrivers, truck owners and the Transporters' Associations that lead to further delays and border skirmishes at Rusumo. The truck drivers refused these arrangements because they had no endorsement from their employers or truck owners, feared incurring excessive costs and could be held accountable for any lost goods[8]. Following delays, unprecedented queues of trucks, truck drivers crowding, truck drivers' protests blocking their colleagues from Rwanda from entering the country presented at Rusumo. Chaos that developed at the Rusumo border point left more than 1,000 trucks destined for Rwanda stuck at a Tanzanian border town [12]. To ease the situation, Tanzania and Rwanda officials agreed to drop the relay driving/trucking system but mandating offloading of cargo at the border "except for trucks carrying perishable goods and petroleum products destined to Rwanda [that would] be escorted at no cost to their final destinations $[8,12]$. Until the time of writing this paper, the situation at is border point was still uncertain.

\subsection{Tanzania-Kenya border}

Kenya shares the border with Tanzania, where Namanga, Sirari, Lunga Lunga and Horiri are the official border crossing points. On May 16, 2020, Kenya closed its borders with Tanzania and Somalia due to increased cross-border infections of the coronavirus [1315]. The Kenyan government took that decision after 43 (14 in Wajir, 16 in Namanga, two in Lunga Lunga and one in Loitoktok) people crossed from the two countries, importing cases into Kenya. On 6 May, the Kenyan President stated that 29 people with a recent history of travel to Tanzania had tested positive in the preceding week [16].

Over the same period, about 182 among 214 who tested positive to COVID-19 at the Kenya-Tanzania border crossings were deported [14,17]. Kenya, established another lab at Naivasha, $92 \mathrm{~km}$ (57miles) northwest of the capital to "test people who might be missed at the border" [14]. Addressing the nation in Nairobi on Saturday, May 16, 2020, the Kenyan President ordered,

Therefore, in accordance to the advice by the National Emergence Response Committee on coronavirus, and the National Security Council, I am directing that there shall be cessation of movement of persons and any passenger ferrying automobiles and vehicles into and out of the territory of the Republic of Kenya through the Kenya-Somali ... and KenyaTanzania... international borders except for cargo vehicles, with effect from midnight today, Saturday $16^{\text {th }}$ May, 2020" [13].

Reporting on the same situation, Said [18] informed that the increasing number of truck drivers from Tanzania testing positive for COVID-19 when they cross the border into Kenya, led the Kenyan authorities to not only close all the borders with Tanzania but also deport 182 people who tested positive for COVID-19 back to Tanzania in an effort to protect Kenyans from the pandemic. The President further clarified that "Cargo vehicles entering Kenya will be subjected to mandatory COVID-19 testing and drivers will be granted entry only if test results are negative" [7,13]. At that time, Kenya had denied entry to 78 truck drivers who tested positive to the virus at the borders [7]. The President announced an extension by 21 days of a dawn-to-dusk curfew [13].

A few days later, the Tanzania Minister for Foreign Affairs and East African Cooperation was quote saying "The government was engaging its EAC neighbors on how to resolve the challenges related to cross-border transmission of coronavirus between Kenya, Uganda and Rwanda" [7]. On 26 March, Kenya had recorded 31 COVID-19 positive cases and one death. The government confirmed that coronavirus cases in the country were spreading among five counties, namely 
International Journal of Advanced Scientific Research and Management, Volume 5 Issue 9, Sep 2020

Nairobi, Kajiado, Mombasa, Kilifi and Kwale. Kajiado and Kwale counties are on the border with Tanzania.

On May $25^{\text {th }}, 2020$, the Tanzanian government reported "Of the 300 truck drivers that were denied entry into Kenya until their had undergone COVID-19 tests, had been allowed to proceed" [19]. A Kenyan official observed, "We have reached an agreement ... One [truck driver] can test in Tanzania and then produce the results certificate at the border to be allowed by Kenyan authorities to proceed with the journey ... Sadly, those who tested positive were denied entry into Kenya" [7,19]. On the same day, the Kenyan Ministry of Health reported it had "turned back 25 truck drivers who tested positive for COVID-19 at the Namanga border point ... They included 23 Tanzanians, a Ugandan and a Rwandan" [19].

Reporting on the mandatory COVID-19 testing among the truck drivers on the Tanzania side of the border, on May 20, 2020, the Arusha Regional Commissioner (RC), reported 19 Tanzania truck drivers who tested positive for CIVID-19 in Kenya, were declared negative when re-tested in Tanzania $[7,17,20]$. The RC further disclosed,

On May 12, samples of 44 truck drivers arriving from Kenya sent to the National Health Laboratory Quality Assurance and Training Centre in Dar es Salaam for COVID19 testing returned 13 positive cases, including 11 cases of Kenyan drivers, a Ugandan and one case [whose nationality he withheld]. The rest tested negative .... On May 16, samples from 23 drivers tested found 10 Kenyans positive of COVID-19 while the rest were negative .... [and] 11 truckers from Kenya were waiting for results of samples taken on May 18 [7].

The RC emphasized taking all necessary precautions "to prevent COVID-19 infections from spreading through our boarder at Namanga" [7]. In the same spirit of preventing the spread of deadly coronavirus into Tanzania from Kenya, the Kilimanjaro and Tanga RCs banned Kenyan trucks from crossing the border into Tanzania, while trucks heading to Malawi, Zambia and DRC were not affected [7, 17]. However, as truck drivers' protests at the Namanga border intensified, pushed the regional governments to formulate clear plans to ensure service at vital border points is not crippled. Specifically, "The protests caused hostility between communities and truckers; between truck drivers and the border authorities, and threatened relations between nations that have always lived side by side

in

harmony"

[21].

On May 19, 2020, the Kenya's High Commissioner to Tanzania held a press conference in Dar-es-Salaam where he appealed for diplomatic interventions to resolve the border disagreement caused by the war against coronavirus. The Commissioner reported he had communicated with the Tanzania International Affairs and East Africa Cooperation Minister on this issue. In the Commissioners' view, "Kenya and Tanzania were confronted with a common enemy, the coronavirus pandemic, which called for a common front to fight" [7].

Addressing citizens in Singida Region and the nation in general on May 20, 2020, the Tanzania President revealed receiving two calls (one on May 19 and the other on May 20) from the Kenyan President where they discussed about COVID-19 responses, the border closure and minor conflicts at border posts of which they agreed to resolve. The President stated in respect to the long-standing brotherhood relations between the two nations, they had directed responsible ministers to meet promptly to resolve the border crisis [7,22,23].

The President indicated that the Minister for Works, Transport and Communications and his Kenyan counterpart would lead the talks in search for a solution on the recently imposed COVID-19 restrictions at border areas. Other members on the Tanzania team were RCs from five regions adjacent to the border: Kilimanjaro, Arusha, Tanga, Mara and Mwanza. Speaking of 'minor conflicts at border posts', the President insisted,

It's illogical for Kenya and Tanzania to engage into unproductive tussles given the fact that the two countries have all along been trading partners ... It's impossible that all drivers are suffering from COVID-19 and it is also impossible for all trucks from Tanzania to be barred from crossing to Kenya and vice-versa ... We want to exploit the benefit of borders by doing business with our colleagues from Kenya ... COVID-19 should not bring about misunderstandings with our neighbors [22].

At the time of writing this paper the situation at this border point had cooled down but not completely settled; thus, further impacting relationships between the borderlanders and the truck drivers; between the truck drivers and the border authorities, and between the two EAC Partner states. 
International Journal of Advanced Scientific Research and Management, Volume 5 Issue 9, Sep 2020

\subsection{Kenya-Uganda border}

Busia and Malaba are the official border crossing points along the Kenya-Uganda border. Following border closing (in mid-March) and the mandatory COVID-19 testing requirement for the truck drivers, on June 25 , 2020, a line of lorries at Busia point stretched 60 kilometers [24], 2020) and "The paralysis at the Uganda-Kenya border had more than doubled the time for goods to move from Mombasa to the Ugandan capital Kampala and raised costs by up to 40 per cent" [26]. Commenting on the impact of COVID-19 screening and testing at the Kenya-Uganda border points of Busia and Malaba, one of the experienced cross-border truck drivers observed, "Trucks that normally take three days to move from Mombasa to Kampala now take eight days ... If this continues for up to six months the drastic will affect the demand side as well" $[21,25]$. Similarly, the border closure over coronavirus was threatening exports of Uganda's fuel supplies [27].

The UN's World Food Program Official observed that COVID-19 screening among the truck drivers at the Kenya-Uganda border crossing points was putting delivery of vital food supplies in East Africa at risk [24], adding, "We could have problems feeding our beneficiaries [hunger-stricken communities and the refugees] ... if the situation doesn't improve ... We are shipping in 2,000 tons of beans and cooking oil to feed some of Uganda's 1.4 million refugees ... Some of it is stuck at Kenya's Mombasa port and some is stuck at the Ugandan border" ([26].

In late May 2020, Ugandan officials reported 25 truck drivers had escaped from the testing centers at Malaba and Elegu where their results showed they were COVID-19 positive. However, seven of them were arrested in "Ndeeba area, on the south-western edge of the capital, Kampala, which is $191 \mathrm{~km}$ (118 miles) from the border" [28]. In Kenya, two truck drivers (one Ugandan and the other a South Sudanese) escaped from a testing center at Busia before their results came out. They were found in Kisumu City (a two-hour drive from the border) and put under isolation as they had tested positive for COVID-19. Again, until the time of writing this paper the situation at this border had not been settled.

\subsection{Uganda-Tanzania border}

Tanzania and Uganda share a border where Mutukula and Isingiro are the official border crossing points. However, Mutukula is the main point through which trucks cross the border into and from Uganda. On March
25, 2020, Uganda's President stopped all passengers coming into Uganda by air, land or water. This order not only "affected in-coming planes, buses, taxis or boats but also prohibited from entry pedestrians trekking on foot from Uganda's neighbors in East Africa" [29]. On April 23, 11 Tanzania trucker drivers who entered Uganda via Mutukula tested positive for COVI-19 that made Ugandan authorities to blame Tanzania for not announcing lockdown [30], compelling the Minister for Health (Uganda) to declare, "All truck drivers arriving via Mutukula point of entry will be tested for COVID19 and results given within 45 minutes ... If you [truckers] are found positive, you cannot proceed with your journey ... if you're negative, you are released" [7].

On Friday, May 15, 2020, the Ugandan government tested 1,838 samples form truck drivers of whom 43 tested positive to the virus: 17 Ugandans, 14 Kenyans, five Tanzanians, two Burundians, four Eritreans and one of unknown nationality [7]. Records indicated the truck drivers were from Mutukula (on the border with Tanzania), Malaba (on the border with Kenya) and Elegu (on the border with South Sudan) border points.

To ensure that all track drivers arriving via Mutukula undergo COVID-19 test, Uganda commissioned a Port Health COVID-19 laboratory at the main UgandaTanzania border point, Mutukula in April and deployed 20 more health workers (topping to 30) [31]. The laboratory is equipment with two GeneXpert machines capable of processing 64 COVID-19 samples per hour [32]. As the number of Tanzanian track drivers testing positive to COVID-19 spiked, the Uganda authorities deployed police and the military along the TanzaniaUganda border (from Kasensero southwards to Isingiro) to control people from crisscrossing the border from either side [33]. At the time of writing this paper border control on the Uganda side of the border was still tight.

\subsection{Uganda-South Sudan border}

Uganda shares the border with South Sudan with EleguNimule as the main official border crossing point. The two countries closed the border on March 23, 2020. In early April 2020, the Amuru district officials complained of truck drivers' misconduct violating the imposed curfew, adding "dozens of truck drivers and operators are also spending nights in various lodges in Elegu Town Council which are operating in violation of the presidential ban to contain the spread of coronavirus" [34]. On April 2, 2020, Amuru authorities closed 12 lodges in Elegu border post alleged for defying presidential directives on COVID-19 prevention measures [35]. 
On Saturday May 31, 2020, Uganda registered 50 COVID-19 positive cases of truck drivers who entered the country form South Sudan via Elegu border point. Residents in that borderland together with their Members of Parliament (MPs) demonstrated against the continuous movement of trucks to and from Elegu border post in Amuru. One of the posters they carried read "Truck drivers in Elegu are intentional"; meaning truck drivers 'have been sent to spread' the virus in that area [34]! A few days before, activists in Amuru had "asked the government to quarantine Elegu border post to curtail the spread of the deadly disease, especially by truck drivers" [36].

Updating the nation on the war against COVID-19, the Ugandan President accused truckers crossing the border into Uganda from South Sudan of carrying passengers into Uganda and "so spreading the virus" [37]. The President's claim followed after "some 280 drivers carrying freight from Uganda to Juba had contracted COVID-19, half of them Ugandans [24]. Earlier in March, Uganda had sent 250 South Sudan citizens alleged to have entered the country illegally and could be coronavirus-infected [38]. On May 9, 2020, there were more than 1,000 cargo trucks transporting petroleum, food items and construction materials parked at Elegu Border Post [39]. By September 1, 2020, Uganda had proposed a $\$ 70$ coronavirus testing charge for volunteers and arrivals including truck drivers. Like other borders discussed, COVID-19 related contentions over the border were ongoing at the time of writing this paper.

\subsection{Tanzania-Zambia border}

Although not located in East Africa, experience at the Tanzania-Zambia border, which the Zambian authorities briefly closed to curb the spread of the deadly coronavirus correctly fits into this context. TundumaNakonde is the official border crossing point along this border. On Sunday, May 9, 2020, the Nakonde district (Zambia) recorded 76 new cases most of which were suspected 'imported' from Tanzania [19,40,41]. Zambia, quickly closed and started monitoring the border with Tanzania very closely on May 11, 2020. As a result, border crossing services at the TundumaNakonde border point froze. On May 24, 2020, the Chairperson of Clearing Agents Association (Tanzania) at the border said the Zambian government had ordered clearing of oil truckers destined for Zambia, stating,

We were asked to clear oil tankers and avert creating a petroleum crisis in Zambia [but] we refused ... We want the government of Zambia to allow all vehicles [to all countries other than
Zambia] at the border to be cleared. [In addition] we thought the decision to allow only oil tankers was not in good faith, rather it was simply meant to help one country in its petroleum requirements [19].

By the end of the day on May 25, 2020, there were about 1,500 trucks stranded at the Tunduma-Nakonde border point some carrying (COVID-19) Medicare supply and equipment, perishables or petroleum products that could easily explode. Clearing Agents Association had "asked the Tanzania Revenue Authority (TRA) to ensure that they do not allow the processing of oil tankers only at the expense of others [countries and drivers]" [19]. The Muchinga Province (Zambia) Minister attested they would give priority to trucks entering Zambia with essential cargo of food, fuel and medical supplies, adding, "What will inform us [when to re-open the border] is the extent to which we disinfect the town and test people" $[42,43]$. Since then, the border communities pleaded the governments to take realistic measures and flexibility in applying the border crossing laws, rules and procedures, harmonizing virus testing and sharing results indicated on certificates carried by border crossers.

On May 13, however, the Tanzania Minister for Foreign Affairs and East Africa Cooperation rebuked claims stating, "Zambia had not closed the border with Tanzania ... Zambia suspended operations at Nakonde border for five days [May 11-15] so as to devise a proper arrangement that will help to contain the spread of the novel Coronavirus ... [Adding the two countries were] scheduled to hold a strategic meeting which seeks to discuss challenges accelerated by the pandemic." [44]. However, Zambia reopened the border with Tanzania on May 15, 2020 [45].

\section{Tanzanian truck drivers stigmatized as coronavirus supperspreaders in the region}

With increased number of truck drivers reported COVID-19 positive, the national officials in the region, mainly in Kenya, Uganda and Rwanda and communities along the transit routes, suspected long-distance truckers of carrying the dreaded coronavirus along with their cargo [12]. Cross-border transmission of the virus became a concern among EAC Patterner States [46]. The President (Uganda), the Minister for Heath (Uganda) and the Cabinet Secretary for Health (Kenya), for example, repeatedly claimed truck drivers were a new concern area of coronavirus spread in East Africa. Addressing the press conference in April, the Ugandan 
International Journal of Advanced Scientific Research and Management, Volume 5 Issue 9, Sep 2020

President, for example, remarked, "We need the cargo ... We need the goods ... But at the same time, we don't want the disease ... So, don't touch the driver, and the driver should not touch you" [12]. In early May, Uganda media quote the President stating, "It is clear... the remaining sources of the disease are the truck drivers within Uganda and the region" and Rwanda attributed rise in COVID-19 cases to truck drivers and their assistants arriving from Tanzania [34].

A health worker at Mutukula Port Health Center claimed, "It is certainly so challenging and risky to the health workers deployed to do work here ... We are handling the already identified unsafe group who are transit truck drivers that are already exposed to the virus," [47]. In addition, on May 11, the Uganda People's Defense Forces (UPDF) Deputy Spokesperson warned Ugandans to stay away from cross border trucks in order to reduce contact with persons who could be infected with coronavirus (COVID-19) disease. Likewise, the official warned sex workers to equally stay away from the drivers because of the dangers they pose, stating,

The same thing goes to the ladies who move alongside these truck drivers ... This has been so common on the eastern border joining the northern border into South Sudan ... We shall put in place all measures to see that this is handled for the good of their lives ... We call upon people on these roads to continue adhering to these directives so that we fight this disease successfully [33].

According to Wasike [21], The Independent [34], Mbewa [46] and Njeru [48], as the number of truck drivers testing positive for COVID-19 kept rising, Rwanda introduced relay driving system and offloading cargo at the border points and locked out Kenyan truck drivers. Drivers failing to comply would have to pay a $\$ 500$ fine. Similarly, Rwanda proposed deploying a surveillance mechanism to monitor the truck drivers' health and behaviors en route to their destinations so that they do not interact with the communities. Uganda planned introducing sanitization of trucks from outside the country at the border point before handling them over to Ugandan drivers (relay driving/trucking) who would take the vehicle to the final destination if in Uganda or to the next border point. Both Kenya and Uganda targeted mass testing for COVID-19 among 'foreign' truck drivers and deploying mobile lab clinics at border crossings. Kenya proposed "goods be transported by train from Mombasa to Naivasha and truck drivers tested there before entering Uganda" [49].
The EAC (Health) Secretariat proposed four testing centers along the Mombasa-Malaba transit route: Mombasa, Kemri-Nairobi, Eldoret and at MalabaUganda border. Uganda launched COVID-19 testing (using GeneXpert machines) and isolation camps at border points, mainly at Mutukula (on the border with Tanzania) and Malaba (on the border with Kenya). For a few days, Tanzania denied border access to Kenyan vehicles stating most of the drivers tested positive for coronavirus. Uganda, Rwanda and Kenya repatriated truck drivers who tested positive for the coronavirus. In addition, Uganda claimed truck drivers from its neighbors (Tanzania, DR Congo, Rwanda, South Sudan and Kenya) were increasing the risk of spreading the disease in the region and in every 10 infected people in that country were truck drivers from Tanzania or Kenya. Truck drivers under escort were required to stop at only designated points and rarely allowed to get out of their vehicles to buy food and water or responding to calls of nature! Escorting officers were meant to monitor truck drivers' movements.

Some government officials in both Kenya and Uganda warned their citizens of any form of social interaction with the truck drivers. Quickly, the communities along the transit routes picked the same perspective viewing truck drivers, Tanzania truck drivers in particular, as supperspreaders of the deadly coronavirus despite the fact that some of them carried certifications they had tested negative. A Tanzanian trucker with COVID-19 free certificate testified at the Uganda-Rwanda border, saying, "They [community members and officials] are calling us 'corona' ... We are not corona and we are corona-free ... We have certificates on the vehicles, but they are still calling us corona. Why?" [8]. Wasike [21] reported track drivers ferrying essential goods to DR Congo, Burundi, Uganda, Rwanda, Ethiopia and South Sudan from Tanzanian and Kenyan coast "are harassed and attacked because of rumors that drivers are transmitting the coronavirus across East Africa." A Kenyan truck driver transporting oil to South Sudan though Uganda via Namanga border point, for example, reported,

The communities along the routes that we use are attacking us, pelting us with stones whenever we stop to take a rest .... The police, the soldiers, and the governments are all hostile to us fearing that we are not only transporting goods but the deadly virus ... These are the issues that governments need to address [21].

Indicating concern about truck drivers spreading coronavirus in Kenya, a businessman at Namanga observed, "We appreciate the business but you know 
International Journal of Advanced Scientific Research and Management, Volume 5 Issue 9, Sep 2020

that truckers have many stops ... They mingle and interact socially with so many people at restaurants, hotels and nightclubs ... What better way to spread the disease than this way? ... We should ground them" [21]. Another Namanga resident on the Kenyan side claimed, "The truck drivers who tested positive here have been mingling with residents ... They ate at the hotels here, slept in lodgings for three to five days as they waited for the results ... Many people could have been exposed to the virus ... All truck drivers must be quarantined at one place as they wait to be tested" [50].

According to Kakwezi [51], sections of the public in Uganda and Kenya were calling for the 'foreign' truck drivers to stop at the borders so that local drivers can take over the driving from there. A Ugandan official narrated, "We have also instituted a team that guides the [truckers] on how to avoid interacting with the community before results are brought back from Uganda Virus Research Institute ... Still, since there's a lockdown, we don't expect them to go to bars, hotels or lodges where they could have interacted with others" [31].

Truck drivers complained of mistreatment at the border points. One truck driver, for example, reported "I haven't gone home for almost a month now, I've been stuck on this road .... They keep poking my mouth every night when they do the swab test, I'm now in pain ... They've even taken my blood but I don't know what the result is [52]. Another driver feared of being infected, narrating, "I have been here for three days now ... I was just tested and I have to wait for two more days for my results ... As I wait here, I could be exposed to the virus as I do not know who has corona and who doesn't' [50].

\section{Tanzania's reaction}

Contrary to her neighbors, Tanzania never imposed curfew, lockdown or close its borders. Instead, Tanzania decided to keep its air, land and water borders open with no formal restriction on internal movement between regions and neighboring countries. International passenger flights continued until April 12, 2020 more than two weeks after Uganda and Kenya suspended all flights, and then reopened on May 18, 2020 [53]. The Tanzanian government allowed citizens to conduct their usual activities while adhering to all health guidelines from the government via the Ministry of Health, Community Development, Gender, Elderly and Children (MoHCDGEC) intended to combat the spread of the noxious coronavirus. The Tanzanian President justified the decision as the need for a lifeline for landlocked countries (particularly Uganda, Rwanda, the DRC, Zambia and somehow Zimbabwe) in the region. The Deputy Minister for Health (Tanzania) noted that "When you go for a total lockdown it means some will instead die of hunger" [53]; the Minister for Foreign Affairs and East Africa Cooperation added, "Coronavirus is dangerous ... but lack of essential services such as food, fuel and medical supplies to landlocked countries could be more damaging" [44].

\section{Discussion}

Our presentation clearly suggests that COVID-19 caught the EAC Partner States unaware and unprepared to wage war against the pandemic as a bloc. As clearly observed, "The confusion witnessed at East Africa's border points demonstrated the consequences of a discordant approach to the Covid-19 pandemic, and the relative lack of depth of regional mechanisms, or commitment to them" [54]. The six Partner States recorded the first COVID-19 cases between March 12 and April 5, 2020. Certainly, governments panicked and instituted uncoordinated containmnent measures including: adhering to strict respitatory hygiene and sanitation guidelines (washing and sanitizing hands regularly); closing learning institutions and other recreational venues; social distancing; restricitng citizens' movement, curfews and partial/full lockdown; international flights cancellation; restricitng free movement of cargo across the region by air, road and water and closing borders for the public health good.

The East African Secretariat's COVID-19 Response Plan and the Administrative Guidelines to Facilitate Movement of Goods and Services During the COVID19 Pandemic documents came out in April when each Partner State had taken its path deemed appropriate to protect its citizenry from coronavirus infection. Rwanda is one of the first countries in Africa to impose a total lockdown as a preventive measure to the spread of corona virus [55]; "shut schools and churches for two weeks and banned concerts and large gatherings ... Its national airline RwandAir canceled flights to India, Israel and China immediately [56]. Tanzania closed schools (pre-school to high schools) instantly. Uganda closed schools and worshiping places even before recording any COVID-19-related death! Rwanda, Uganda and Kenya closed the borders without consultations with adjoining Partner States [57]. Rwanda and Uganda were the first Partner States to suggest for relay driving/trucking that infuriated truck drivers leading to protests at Rusumo at the border with Tanzania and Busia and Malaba on border with Kenya, 
International Journal of Advanced Scientific Research and Management, Volume 5 Issue 9, Sep 2020

respectively. To effect mass testing, in mid-May, Rwanda deployed the United Nations Development Programme (UNDP)-donated "high-tech robots given Rwandan names [with] the capacity to screen 50 to 150 people per minute, deliver food and medication to patient rooms, capture data and notify officers on duty about detected abnormalities" [58].

Other African countries faced a similar situation. Libya was the first country on the continent to close its borders on March 13 followed by South Africa on March 15. By March 24, 25 countries had closed their borders for public health good [59]. Senegal, South Africa, Zambia and Ethiopia hastily closed educational facilities to avoid crowding places. Botswana, Ghana and Ethiopia banned sporting events while DRC and Ghana banned gatherings at worship places [12].

Following the release of the two documents in April, in May, Presidents of the four EAC Partner States (Rwanda, Uganda, Kenya and South Sudan) held two online COVID-19-related consultative meetings organized by the East African Community (EAC) Secretariat. The heads of states "tasked their agencies responsible for health, transport and EAC affairs to roll out border screening and testing, especially for truck drivers, but not to compromise cross-border movement of goods" [19]. Similarly, the Heads of the Southern African Development Community (SADC) held meeting with the same agenda. At this meeting, the regions' heads of states agreed on executing unified measures to curb the virus including harmonizing certification and COVID-19 test results sharing [19]. Tanzania did not participate in the three meetings due what the Minister of International Affairs and East African Cooperation explained as unscheduled meetings of the two blocs [44], which raised some eyebrows among other members of the two blocs. Unquestionably, the truck drivers' experiences presented demonstrate that closing borders, imposing curfews and lockdown to avert COVI-19 spread greatly interrupted the free movement of people, goods and services in the region and in some cases resulted into human rights violations.

The importance/contribution of truck drivers to the social, political and economic development in the region and more so during the COVID-19 pandemic, cannot be over emphasized. Dar es Salaam port is an important access route to seven land-linked and landlocked countries including DRC, Burundi, Malawi, Rwanda, Uganda, Zambia and (somehow) Zimbabwe as it also provides a gateway for $90 \%$ of Tanzanian trade $[43,44]$. It is estimated that the value of cargo moved through the border destined for Zambia, DRC and Zimbabwe valued at $\$ 1.5$ billion per annum [43]. Certainly, continued closure of this border to control the spread of the deadly coronavirus would have been a disaster to the economies of these countries and Tanzania.

Tanzania and Kenya have been key trading partners in the region; where Tanzania is the top Kenya's exports' destination [22]. It is estimated that in 2018, Tanzania's imports from Kenya (plastics, iron and steel, machinery, animal and vegetable fats, electrical equipment and vehicles) valued at 338.83 million US dollars while Kenya's imports from Tanzania (cereals, wastes of the food industry, paper and paperboard, beverages, spirits and vinegar) amounted to 293.7 million US dollars [60]. Evidently, the continued closure of the Kenya-Tanzania border could have had negative impact on the economies of the two countries [25].

However, the truckers, the unsung heroes, serve the region under difficult conditions as observed by Wadekar [12]:

Long haul truck drivers have a difficult job ... They transport goods from the coastline along poorly-paved and dangerous roads in Tanzania and Kenya, up to Uganda and beyond into the Democratic Republic of Congo and other Central [and South] African nations ... Along the way, they often interact with corrupt police officials eager to take whatever bribes they can elicit in return for continued passage.

In the COVID-19 period, truck drivers are designated as essential workers because they are transporting critical goods such as food, petroleum products, medication and equipment within the region. The Arusha-based East African Business Council (EABC), for example, issued a Statement that, "truck drivers were among those risking their personal health to keep products moving to stores, hospitals, homes and elsewhere during the COVID-19 pandemic" [10]. In part, the Statement further reads,

Despite the impact of COVID-19, truck drivers continue to deliver essential commodities including food, personal protective equipment (PPE), medicines, raw materials within and across the East African Community (EAC) borders ... The EABC appreciates and recognizes the selfless dedication of truck drivers who are delivering goods to health facilities, factories and consumers ... This will boost the availability of medical, PPEs and food crucial to protecting the health of our citizens and improving food security in the 
International Journal of Advanced Scientific Research and Management, Volume 5 Issue 9, Sep 2020

region ... Stigmatization against truck drivers should never be an option, as this may lead to a disruption in the supply chain in the EAC member countries, thus affecting further trade and investment ... Let us support our truck drivers in the region, our unsung heroes on the wheel delivering essential cargo into and out of our countries [10].

Updating the nation on COVID-19 status, the Uganda President remarked, "Uganda can't afford stopping truck drivers from entering the country since it is a landlocked country ... [Adding] further restricting driver movements would harm Uganda's economy ... The country [Uganda] will not be able to sell its agricultural products like coffee, tea, cotton among others" [58].

Relay driving, in which truckers stop at the border, sanitize their vehicles and pass along their goods to another driver so that they do not cross international lines, proposed by Rwanda and Uganda, fueled anger among the truckers, vehicle owners, Transporters' Associations and the governments/border authorities. While the governments imposed this measure to control the deadly coronavirus spread for the public heath good; the truckers, vehicle owners and Transporters' Associations used the economic lens to evaluate the situation: providing services at optimum costs. The Chief Operating Officer at the Kenya Transporters' Association (KTA), for example, expressed that relay driving/trucking,

Would require new drivers' recruitment and training and would drastically increase the cost of transportation to the trucking companies while the business has been affected by reduced cargo volumes and longer transit times ... [Adding] that this would also incur additional expenses in providing accommodation for additional drivers ... [worried of] security and safety of the cargo, which would be compromised by multiple drivers involved in a single haulage ... Truckers would face challenges in tracing driver's responsibilities on trucks misuse, damages and theft of fuel ... Relay drivers would raise the challenges with regards to insurance as any accident or theft would likely be challenged by the insurance companies [61].

It is clear that the governments intended to impose relay driving/trucking without engaging transport stakeholders and the EAC Secretariat to help come up with a workable cargo movement approach within the region during the COVID-19 pandemic as suggested by the EAC Secretariat.

Truck drivers' stigmatization as supperspreaders of coronavirus in the region could be explained as follows. First, the scientists and the media alike have internationally portrayed COVID-19 as a more dangerous disease than Ebola and other pandemics that 'originated' in China and 'exported' to the rest of the world. This presentation has served to create fear worldwide directed towards particular people thought most likely to carry the virus: those who travel [62]. By the nature of their job, truck drivers are highly mobile within and across borders, which puts them at risk of contracting and spreading the virus. In this context, some communities and the political elite in the EAC bloc, believe and perceive truckers as reservoirs of coronavirus and conduits of COVID-19.

Second, previous HIV and AIDS (1980s-2000) studies conducted in the region concluded that because truck drivers are a highly-mobile vulnerable group that crisscrosses their home countries and beyond, often spending nights in temporary locations, interacting with sex workers and where exposure is high and testing and protection use is low; put them (truck drivers) at higher risk of contracting and spreading sexually transmitted infections (STIs) including HIV. Majority of East African communities and the elite alike; still have memories of the spread of HIV and AIDS in the region where 'the foreigners', the long-distance truck drivers and female sex workers (FSW) were initially concluded key spreaders of AIDS in the region [63].

From this perspective, truck drivers carrying essential goods across borders in the region may also be carrying Coronavirus and transmitting COVID-19. To limit this course, truckers should undergo mandatory testing and their en route movements and behaviors be closely monitored and controlled. Commenting on allegations that truckers were spreading COVID-19, Kenyan doctors warned,

It is too soon to begin pointing the finger at truck drivers as carriers or spreaders of COVID-19, and that [such allegations] could lead to widespread discrimination against drivers. [Adding] We should test them first and see the prevalence in comparison with the general population $[100,000$ per $1,000,000$ population] ... They could be at risk but making that [allegation] without any solid evidence can lead to stigma [12]. 
International Journal of Advanced Scientific Research and Management, Volume 5 Issue 9, Sep 2020

In turn, widespread discrimination and stigmatization of truck drivers could negatively erode (from hospitality to hostility) long-rooted amicable relationships between truckers and communities along transit routes and between adjoining nation states.

Third, as indicated earlier, EAC countries, except Tanzania, closed their borders well in advance even before recording any COVID-19-related death to curb the spread of the disease and without consulting other Partner States. A range of border controls and mandatory testing for COVID-19 among border crossing persons, the truckers in particular, were deployed specifically to limit free movement of people who could import the coronavirus and transmit COVID19 disease. As the number of truckers testing positive for COVID-19 at border points spiked, Rwanda, Uganda, South Sudan and Kenya tightened their border controls against the 'foreigners'. Long waiting time for testing or test results at border points resulted into truckers crowding that could have put them at risk of being infected and even infecting hosting communities. Truck drivers mingle with hosting communities, which could put them of being infected or infecting others. The elite's announcement that the truck drivers were carrying the virus along with their cargo fertilized fear among border communities.

Finally, for the Tanzanian track drivers, the crisis was more distinct at Mutukula, Rusumo and Namanga border points with Uganda, Rwanda and Kenya in that order. Tanzania took a different and unique path to fight COVID-19: keeping its borders open, denied curfews and lockdowns, temporarily suspending events that could lead to crowding, using medicinal herbs, praying and more importantly, learning to live with the disease [64]. On April 29, Tanzania had recorded a total of 408 COVID-19 cases. Since then, the number of COVID-19 cases was reported decreasing substantially. Tanzanian authorities concluded God had answered the prayers and the then suspended activities/functions resumed from June 1 .

Tanzania's strategy of fighting the deadly disease has raised concerns among its neighbors, the region and international entities. Some observers claim Tanzania authorities are covering the true picture of COVI-19 impact, thus mistrusting the claimed situation in the country. In the authors' view, it is the mistrust and created fear that made residents in Rwanda, Uganda and Kenya perceived Tanzanian truckers as supperspreaders of COVID-19 in the region. However, mistreating truckers at border points, mistrusting COVID-19 test results certified by the other EAC Partner State and repatriating COVID-19 positive truckers or their crew violated the EAC COVID-19 guidelines and their right to health and healthcare.

\section{Conclusion and recommendations}

Indeed, like anywhere on the globe, COVID-19 is affecting all spheres of life in East Africa. The region's unpreparedness to fight the disease as a bloc, led to uncoordinated measures taken by EAC Partner State individually mostly mimicking measures taken in the developed world that somehow do not fit in the region's context. Closing borders for the public health good and mandatory testing for COVID-19 among the truck drivers have disrupted the free movement of people, goods and services in the region and are eroding amicable relationships that previously existed among the truck drivers; between communities along the transit routes/interregional highways and the truck drivers; between the truck drivers and border authorities; and somehow between adjoining EAC Partner States.

COVID-19 is not the first virus African societies have confronted. Deploying experiences from fighting pandemics that hit Africa in the past, even before encounters with the western world [65-67], such as Small pox, Black death, Chicken pox, measles, Crimean-Congo hemorrhagic fever, Spanish flue, HIV and AIDS, Rift Valley Fever (RVF), Swine flu, Ebola and Zika would benefit nurturing historical and deeproot relationships among societies and nations on the continent. Yes, COVID-19 has temporarily divided the bloc and it will continue challenging the region until the vaccine or cure is in place; "but the baby shouldn't be thrown out with the bath water" [68]. Our presentation challenges the 'One-size-fits-all' model. We recommend, the fight against COVID-19 and similar challenges must be tailored to Africa's realities and informed by research conducted on the continent and involving its own scientists.

\section{Acknowledgements}

We, authors, acknowledge colleagues at the Muhimbili University of Health and Allied Sciences (MUHAS) for reading and commenting on earlier versions of this paper.

\section{References}

[1] Shereen, M. A., Khan, S., Kazmi, A., Bashir, N., Siddique, R. COVID-19 infection: Origin, transmission, and characteristics of human 
coronaviruses. (2020). Available at: https://reader.elsevier.com/reader/sd/pii/S209012322 0300540?token=3FF23C7AA7725D4D806D0B2B4 BFD3555A7C142BD9B8BE6CAA048133F1055BF 60AA351AD9765451204795495711DAC8C5

Accessed on June 24, 2020.

[2] Rothan, H. A. and Byrareddy, S. N. The epidemiology and pathogenesis of coronavirus disease (COVID-19) outbreak. Journal of autoimmunity. 109:102433. (2020). https://www.sciencedirect.com/science/article/pii/S0 896841120300469 Accessed on June 24, 2020.

[3] Worldometer. COVID-19 Coronavirus Pandemic. (2020). Available at: https://www.worldometers.info/coronavirus/ Accessed on September 3, 2020.

[4] Aluga, M. A. Coronavirus Disease 2019 (COVID19) in Kenya: Preparedness, Response and Transmissibility, Journal of Microbiology, Immunology and Infection. (2020). Available at: https://

doi.org/10.1016/j.jmii.2020.04.011 Accessed on June 16, 2020.

[5] The East African Community Secretariat. East African Community (EAC) Administrative Guidelines to Facilitate Movement of Goods and Services During the COVID-19 Pandemic. Arusha, April. (2020a). Available at: http://repository.eac.int/handle/11671/2058

Accessed on June 2, 2020.

[6] The East African Community Secretariat. East African Community COVID-19 Response Plan. Version 5. Arusha. (2020b). April. Available at: https://www.eac.int/press-releases/147-health/1721eac-unveils-covid-19-response-plan Accessed on June 2, 2020.

[7] The Citizen Reporter. Tanzania: Arusha Regional Commissioner Now Turns the Heat On Kenyan Drivers Over COVID-19 Tests. (2020a). The Citizen. Dar es Salaam. 20 May. Available at: https://allafrica.com/stories/202005200916.html Accessed on May 22, 2020.

[8] Nambi, C and Chombo, A. Fear of COVID-19 Slows Trucking in East Africa. (2020). Available at: https://www.voanews.com/covid-19-pandemic/fearcovid-19-slows-trucking-east-africa Accessed on May 22, 2020.

[9] Mugisha, I. R. Tanzania, Rwanda strike a deal on truck drivers. The East African. May 16. (2020). Available at: https://www.theeastafrican.co.ke/news/ea/TanzaniaRwanda-strike-a-deal-on-truck-drivers/45529085554344-15juxyp/index.html Accessed on May 20, 2020 .
[10] Xinhua. East African truck drivers praised over delivery of goods amid COVID-19 crisis. (2020a). Available at: http://www.xinhuanet.com/english/202005/20/c_139072933.htm Accessed on May 22, 2020.

[11] Kagire, E. Rwanda, Tanzania Move to Tackle Cross-border Truckers' Protests. KTPress. May 5. (2020). Available at: https://www.ktpress.rw/2020/05/rwanda-tanzaniamove-to-tackle-cross-border-truckers-protests/ Accessed on May 20, 2020.

[12] Wadekar, N. East African truck drivers carrying essential goods cross-border may also be transmitting COVID-19. Quartz Africa. April 28. (2020). Available at: https://qz.com/africa/1846942/uganda-worriedkenya-truckers-transmit-covid-19-in-east-africa/ Accessed on May 20, 2020.

[13] Wasike, A. COVID-19: Kenya closes border with Somalia, Tanzania. [14] Anadolu Agency. (2020a). Available at: https://www.aa.com.tr/en/africa/covid-19-kenyacloses-border-with-somalia-tanzania-/1843664 Accessed on June16, 2020.

[14] Anadolu Agency. Zambia shuts border with Tanzania to curb COVID-19. (2020). Available at: https://www.aa.com.tr/en/africa/zambia-shutsborder-with-tanzania-to-curb-covid-19/1836623 Accessed on August 13, 2020.[15] Tanui, C. Kenyatta orders closure of Kenya-Tanzania, Kenya-Somalia borders to all passenger traffic. Capital News. May 16. (2020). Available at: https://www.capitalfm.co.ke/news/2020/05/kenyatt a-orders-closure-of-kenya-tanzania-kenyasomalia-borders-to-all-passenger-trafficl Accessed on May 20, 2020.

[16] Mwai, P. and Giles, C. Coronavirus in Tanzania: What do we know? (2020). Available at: Available at: https://www.bbc.com/news/worldafrica-52723594 Accessed on June 8, 2020.

[17] Kibii, E. Covid-19 reignites Kenya-Tanzania historical hostility. Star. 23 May. (2020). Available at: https://www.thestar.co.ke/siasa/2020-05-23-covid-19-reigniteskenya-tanzania-historical-hostility/ Accessed on June 8, 2020.

[18] Holmes, C., Boyce, M and Katz, R. Africa is not Starting from Scratch on COVID-19. Infectious Disease Atlas. (2020). Available at: https://www.thinkglobalhealth.org/article/africanot-starting-scratch-covid-19 Accessed on June 8, 2020.

[19] Mikomangwa, P. Virus update: COVID-19 induced East Africa's border saga. The Exchange. 
International Journal of Advanced Scientific Research and Management, Volume 5 Issue 9, Sep 2020

May 26. (2020a). Available at: https://theexchange.africa/countries/virus-updatecovid-19-induced-east-africas-border-saga/ Accessed on August 13, 2020.

[20] Maina, N. Tanzania doubts Kenya's CIVID-19 tests. PD Online. May 20. (2020). Available at: https://www.pd.co.ke/news/tanzania-doubtskenyas-covid-19-tests-37372/ Accessed on May 21, 2020.

[21] Wasike, A. East African truckers face backlash from COVID-19. Anadolu Agency. May 17. (2020b). Available at: https://www.aa.com.tr/en/africa/east-africantruckers-face-backlash-from-covid-19/1843735 Accessed on May 22, 2020.

[22] Luhwago, R. Tanzania: JPM, Uhuru Solve Border Puzzel. Daily News. May 21. (2020). Available at: https://allafrica.com/stories/202005210237.html Accessed on May 22, 2020.

[23] Cheploen, N. Presidents Uhuru, Magufuli call eases tension at border. PD Online. May 21. (2020). Available at: https://www.pd.co.ke/news/presidents-uhurumagufuli-call-eases-tension-at-border7519/?utm_source=website\&utm_medium=corona virus\&utm_campaign $=$ coronavirus\&utm_term $=\mathrm{co}$ ronavirus Accessed on May 21, 2020.

[24] Padmore, R. East African lorry drivers worry about stigmatization. BBC News. June 3. (2020). Available at: https://www.cfr.org/blog/politicsfood-time-covid-19 Accessed on June 8, 2020.

[25] Ilako, C. and Amadala, V. Kenya and Tanzania border spat to erode free trade gains. Coronavirus war splits Kenya and Tanzania. Star. May 20. (2020). Available at: https://www.thestar.co.ke/business/kenya/2020-05-20-kenya-andtanzania-border-spat-to-erode-free-trade-gains/ Accessed on June 8, 2020.

[26] Awori, D. Uganda: Trucks, Fuel Tankers held at Busia Border Over COVID-19. The Monitor. March 27. (2020). Available at: https://allafrica.com/stories/202003270694.html Accessed on June 19, 2020.

[27] Reuters. Coronavirus-induced border bottlenecks slow food deliveries in East Africa. The East African. (2020). Available at: https://www.theeastafrican.co.ke/news/ea/Coronav irus-border-bottlenecks-slow-deliveries-EasyAfrica/4552908-5567342-krs7i3/index.html Accessed on June 19, 2020.

[28] Atuhaire, P. Ugandan sex workers risk their lives in lockdown. BBC News. 29 May. (2020). Available at: https://www.cfr.org/blog/politicsfood-time-covid-19 Accessed on June 8, 2020.
[29] Muhangi, K. Uganda's COVID-19 fight: Defying the odds to contain a global pandemic. (2020). Available at: https://www.newvision.co.ug/news/1518398/ugan da-covid-19-fight-defying-odds-contain-globalpandemic Accessed on June 8, 2020.

[30] Tugume, J. 11 cargo transporters test positive for COVID-19. New Vision. April 24. (2020). Available at: https://www.newvision.co.ug/new_vision/news/15 18217/cargo-transporters-test-positive-covid-19 Accessed on May 20, 2020.

[31] Musasizi, A. COVID-19: Twenty more medics to be deployed at Mutukula border. National Media. April 27. (2020b). Available at: https://www.monitor.co.ug/News/National/Twenty -more-medics-be-deployed-Mutukula-bordercovid-19/688334-5535550-13lq1ksz/index.html

Accessed on May 20, 2020.

[32] World Health Organization (WHO). Uganda commissions Port Health COVID-19 laboratory at the main Uganda-Tanzania border point. (2020). Available at: https://www.afro.who.int/news/ugandacommissions-port-health-covid-19-laboratorymain-uganda-tanzania-border-point Accessed on May 20, 2020.

[33] Dispatch. Ugandans using trucks to flout transport ban, hampering efforts to stem COVID19 spread. May 11. (2020a). Available at: https://www.dispatch.ug/2020/05/11/ugandansusing-trucks-to-flout-transport-ban-hamperingefforts-to-stem-covid-19-spread/ Accessed on May 20, 2020.

[34] The Independent. All Ugandan truck drivers to be tested. May 16. (2020a). Available at: https://www.independent.co.ug/all-ugandan-truckdrivers-to-be-tested/ Accessed on May 22, 2020.

[35] Ojara, E. D. 12 Lodges Closed at Elegu Border Post. (2020). Available at: https://ugandaradionetwork.net/story/12-lodgesclosed-at-elegu-border-post Accessed on June 2, 2020

[36] The Independent. MPs Odonga Otto, Gilbert Olanya arrested in Gulu. News. June 1. (2020b). Available at: https://www.independent.co.ug/mpsodonga-otto-gilbert-olanya-arrested-in-gulu/ Accessed on June 2, 2020.

[37] The Independent. Truck drivers on the spot for smuggling in people from South Sudan. April 6 . (2020c). Available at: https://www.independent.co.ug/truck-drivers-onthe-spot-for-smuggling-in-people-from-southsudan/ Accessed on June 2, 2020. 
International Journal of Advanced Scientific Research and Management, Volume 5 Issue 9, Sep 2020

[38] The Independent. Illegal entry by South Sudan nationals into Uganda worries authorities in Amuru. March 25. (2020d). Available at: https://www.independent.co.ug/illegal-entry-bysouth-sudan-nationals-into-uganda-worriesauthorities-in-amuru/ Accessed on June 2, 2020.

[39] Makumbi, C. Uganda: Stranded Cargo Trucks Spark Worry At Elegu. The monitor (Kampala) AllAfrica. May 10. (2020). Available at: https://allafrica.com/stories/202005110217.html Accessed on June 2, 2020.

[40] Xinhua. Tanzania-Zambia border businesses come to standstill over COVID-19 pandemic. Xinhua Net. May 12. (2020b). Available at: http://www.xinhuanet.com/english/202005/12/c_139048446.htm Accessed on August 13, 2020.

[41] Chawe, M. Zambia closes border with Tanzania to tame COVID-19. The East African. May 11. (2020). Available at: https://www.theeastafrican.co.ke/tea/news/rest-ofafrica/zambia-closes-border-with-tanzania-totame-covid-19-1441112 Accessed on August 13, 2020.

[42] Mikomangwa, P. COVID-19 takes new dynamic in Tanzania. The Exchange. May 26. (2020b). Available at: https://theexchange.africa/tag/zambia-tanzaniaborder/ Accessed on August 13, 2020.

[43] The Citizen Reporter. What Zambia border closure means to four countries. The Citizen. May 12. (2020b). Available at: https://www.thecitizen.co.tz/news/-What-Zambiaborder-closure-means-to-four-countries/18403405550056-mxwinc/index.html Accessed on August $14,2020$.

[44] Domasa, S. Tanzania: Govt Clears Up Border Saga. Daily News. Dar-es-Salaa. May 14. (2020). Available at: https://allafrica.com/stories/202005140573.html Accessed on August 13, 2020.

[45] Mfula, C. Zambia reopens border with Tanzania to cargo after COVID-19 closure. Reuters. May 15. (2020). Available at: https://www.reuters.com/article/us-healthcoronavirus-zambia/zambia-reopens-border-withtanzania-to-cargo-after-covid-19-closureidUSKBN22R1XT Accessed on August 13, 2020.

[46] Mbewa, D. O. Uganda denies sending back COVID-19 positive foreign truck drivers. Daily Monitor. April 28. (2020). Available at: https://africa.cgtn.com/2020/04/28/uganda-deniessending-back-covid-19-positive-foreign-truckdrivers/ Accessed on May 22, 2020.
[47] The Independent. Health workers, Covid-19 suspects sharing room at Mutukula border. May 4. (2020e). Available at: https://www.independent.co.ug/health-workerscovid-19-suspects-sharing-room-at-mutukulaborder/ Accessed on May 20, 2020.

[48] Njeru, B. Uganda denies repatriating positive Covid-19 truck drivers. Standard. April 29. (2020). Available at: https://www.standardmedia.co.ke/article/20013695 51/uganda-denies-repatriating-positive-covid-19truck-drivers Accessed on May 22, 2020.

[49] Ahimbisibwe, P. Security to escort drivers Museveni. Daily Monitor. May 13. (2020). Available at: https://www.monitor.co.ug/News/National/Securit y-to-escort-truck-drivers/688334-5551182jnt8n9/index.html Accessed on May 22, 2020.

[50] Kakwezi, C. COVID-19 Updates: How East African Countries are tackling Problem of Truck Drivers. KIU News. May 20. (2020). Available at: https://www.kiu.ac.ug/news-page.php?i=covid-19updates-how-east-african-countries-are-tacklingproblem-of-truck-drivers Accessed on May 22, 2020.

[51] British Broadcasting Corporation (BBC). Coronavirus tests cause tailbacks at KenyaUganda border. News. April 27. (2020). Available at: $\quad$ https://www.bbc.com/news/world-africa52440789 Accessed on May 22, 2020.

[52] Janet, R. Namanga Residents Want Truck Drivers Awaiting COVID-19 Tests Isolated. Kenya News Agency. May 22. (2020). Available at: https://www.kenyanews.go.ke/namangaresidents-want-truck-drivers-awaiting-covid-19tests-isolated/ Accessed on May 22, 2020.

[53] Kell, F. Tanzania Evades COVID-19 Lockdown, but Restrictions Persist. Chatham House. (2020). https://www.chathamhouse.org/expert/comment/ta nzania-evades-covid-19-lockdown-restrictionspersist Accessed on June 8, 2020.

[54] The East African. Confusion at East Africa borders will slow down economies. May 09. (2020). Available at: https://www.theeastafrican.co.ke/oped/editorial/Co nfusion-at-East-Africa-borders-will-slow-downeconomies/434752-5547386-dd3r0d/index.html Accessed on August 18, 2020.

[55] Mbanda, G. Winning the War Against COVID19. KTPress. May 17. (2020). Available at: https://www.ktpress.rw/2020/05/winning-the-waragainst-covid-19/ Accessed on May 20, 2020.

[56] RwandAir. RwandAir to temporarily stop all flights for 30 days. Kigali. March 19. (2020). Available at: https://www.rwandair.com/media- 
center/news-press-releases/rwandair-totemporarily-stop-all-flights-for-30-days/ Accessed on September 3, 2020.

[57] Daily Nation. Ugandan man tests positive for coronavirus - Heath minister. March 22. (2020). Available at: https://www.nation.co.ke/news/africa/Ugandareports-first-coronavirus-case/1066-54999344gpipyz/index.html Accessed on May 20, 2020.

[58] Dispatch. Rwanda deploys high-tech robots in fight against COVID-19. May 20. (2020b). Available at: https://www.dispatch.ug/2020/05/20/rwandadeploys-high-tech-robots-in-fight-against-covid19/ Accessed on May 20, 2020.

[59] Bouët, A. and Laborde, D. COVID-19 border policies create problems for African trade and economic pain for communities. International Food Policy Research Institute (IFPRI). May 12. (2020). Available at: https://www.ifpri.org/blog/covid-19-borderpolicies-create-problems-african-trade-andeconomic-pain-communities Accessed on May 21,2020

[60] United Nations COMTRADE. 2018 International Trade Statistics Yearbook. NY. Volume I. (2019) Available at: https://comtrade.un.org Accessed on August 17, 2020.

[61] Freight Logistics. Transporters petition Uganda government on driver border crossing rules. April 27. (2020). Available at: http://magazine.feaffa.com/transporters-petitionuganda-government-on-driver-border-crossingrules/ Accessed on May 20, 2020.
[62] Oryem, R. Xenophobia and behavioural responses to COVID-19 in Uganda. (2020). Available at: https://blogs.1se.ac.uk/africaatlse/2020/05/01/xeno phobia-racism-ebola-behavioural-change-covid19uganda/ Accessed on June 6, 2020.

[63] Kamazima, S. R. Borders, Boundaries, Peoples and States: A Comparative Analysis of Potindependence Tanzania-Uganda border Regions. PhD Thesis. University of Minnesota. (2003).

[64] Kamazima, S. R., Kakoko, D. V. C. and Kazaura, M. (In press). Multiple approaches to fight modern pandemics in the developing world: a case of Tanzania's tactics to curb COVID-19. In press.

[65] Fako, T. "The dilemma of African Traditional Medicine: The Case of Botswana." In du Toit, B. M. and Abdallah, I. H. (eds.) African Healing Strategies. Owerri. Trdo-Medic Books. Chapter 12. pp. 190-229. (1985).

[66] Chirikure, S. How ancient African societies used social distancing to manage pandemics. May 18 . (2020). Available at: https://qz.com/africa/1858278/how-ancientafrican-societies-managed-pandemics-likespanish-flu/ Accessed on May 19, 2020.

[67] Holmes, C., Boyce, M and Katz, R. Africa is not Starting from Scratch on COVID-19. Infectious Disease Atlas. (2020). Available at: https://www.thinkglobalhealth.org/article/africanot-starting-scratch-covid-19 Accessed on June 8, 2020.

[68] Tetui, M. Coronavirus in East Africa. Think Global Health. April 29. (2020). Available at: https://www.thinkglobalhealth.org/article/coronavi rus-east-africa Accessed on June 8, 2020. 